\title{
Development of a Highly Efficient Hydrometallurgical Recycling Process for Automotive Li-Ion Batteries
}

\author{
Honggang Wang ${ }^{1} \cdot$ Bernd Friedrich $^{1}$
}

Published online: 1 April 2015

(C) The Minerals, Metals \& Materials Society (TMS) 2015

\begin{abstract}
In this paper, an efficient and product-oriented hydrometallurgical recycling process including pre-treatment is developed to handle the spent automotive $\mathrm{Li}-\mathrm{ion}$ batteries. The possibility to recover the high-grade graphite, cathode metal salts and lithium carbonate is investigated. In the designed process, leaching, solution refining, cathode metals precipitation and lithium carbonate crystallisation are implemented. The leaching efficiencies of valuable metals $(\mathrm{Co}, \mathrm{Ni}, \mathrm{Cu}$ and $\mathrm{Li})$ are in the range of 98.6-99.9\% under the optimum conditions: $80{ }^{\circ} \mathrm{C}, 50 \mathrm{~g} / \mathrm{L}$ of hydrogen peroxide, $2 \mathrm{~mol} / \mathrm{L}$ of sulphuric acid or $4 \mathrm{~mol} /$ $\mathrm{L}$ of hydrochloric acid in $2 \mathrm{~h}$. Meanwhile, the filtered graphite with purity of $99.8 \%$ is obtained. In the following $\mathrm{Cu}$ cementation, an optimum temperature of $60^{\circ} \mathrm{C}$ is found and the calculated activation energy of the cementation reaction is $12.9 \mathrm{~kJ} / \mathrm{mol}$. In the hydroxide precipitation, $\mathrm{pH} 3.5-4$ is suggested for $\mathrm{Al}$ and $\mathrm{Fe}$ removal and $\mathrm{pH} 10$ is high enough for cathode metal ( $\mathrm{Co}, \mathrm{Ni}$ and $\mathrm{Mn}$ ) salts precipitation. The carbonate and sulphide precipitation methods are also demonstrated to be successful. In all, several marketable products are obtained, such as graphite, $\mathrm{Cu}$ powder, cathode metal salts and lithium carbonate.
\end{abstract}

Keywords Automotive Li-ion batteries - Cobalt . Nickel $\cdot$ Lithium $\cdot$ Hydrometallurgy $\cdot$ Recycling

Honggang Wang

wanghonggang033@163.com

1 IME Process Metallurgy and Metals Recycling, RWTH Aachen University, Intzestrasse 3, 52056 Aachen, Germany

\section{Introduction}

Nowadays, utilisation of clean energy gets more and more attention due to the large amount of the off-gas exhausted by vehicles and heavy industry. As known, the electric vehicles (EVs) have higher energy efficiency and less $\mathrm{CO}_{2}$ emission than the traditional vehicles. The production and sale of EVs might be widely promoted in the future, especially when the global warming becomes too obvious. For the electric vehicles, the Li-ion battery has the highest opportunity to be widely used due to its outstanding features in comparison with conventional batteries, such as high voltage, high energy density, low self-discharge rate and wide temperature range of operation. It is possible to forecast that the recycling market for automotive lithium-ion batteries (LiBs) will dramatically increase in the near future [1].

Different from a single Li-ion cell, the automotive $\mathrm{Li}-$ ion battery consists of a set of cells. Normally, a certain number of cells are packed together into a unit so-called "module" and the battery is composed of several modules. Therefore, the structure of automotive batteries is more complicated than portable $\mathrm{Li}$-ion batteries. The electrical components, e.g. printed circuit board (PCB), are required to control different modules and cells in voltage and temperature [2].

In the European Union (EU), the directive 2006/66/EC regulates the management of batteries at the end of life. The disposal in landfills or incineration of waste industrial and automotive batteries and accumulators is prohibited. This legislative framework commits producers and traders of all kinds of batteries to take the spent batteries back and assure a state-of-the-art treatment and recycling. Additionally, the recycling rate of spent $\mathrm{Li}$-ion batteries is obliged to reach at least $50 \%$ by weight before September 29, 2010 [3]. 
The recycling processes of $\mathrm{Li}$-ion batteries, which are currently operated in industrial scale in the world, can be divided into three types: pyrometallurgy, hydrometallurgy and pure mechanical treatment. More than 10 companies are recycling thousands of metric tons of spent portable and industrial Li-ion batteries annually. The companies, such as Umicore (Belgium), Xstrata Nickel (Canada), Accurec (Germany), Inmetco (USA), S.N.A.M (France) and SonySumitomo (Japan) use pyrometallurgy as the main recycling process to recycle rechargeable portable and industrial $\mathrm{Li}$-ion batteries also including $\mathrm{NiMH}$ and $\mathrm{NiCd}$ batteries. Valuable metals, such as $\mathrm{Co}$ and $\mathrm{Ni}$, are fully recovered in the form of alloy at high temperature. The other easily vaporised or ignoble metals (e.g. $\mathrm{Al}, \mathrm{Li}$ and Cd) enter in slag or flue dust [4-8].

Diversity in process design is presented in the hydrometallurgical processes. In the Recupyl (France) process, the valuable metals have been recycled as metal salts in the product. A pilot plant for the research project "Lithorec" was built in company Rockwood Lithium (Germany) in which an electrochemical membrane process (Electrodialysis) is used to synthesise $\mathrm{LiOH}$ from the solution. Especially, the Retriev Technologies/Toxco (USA) has applied a cryogenic freezing process to make the $\mathrm{Li}-$ ion batteries fragile, and then crush them before the hydrometallurgical separation [9-11]. Different from the above-mentioned processes, Batrec (Switzerland) focuses on the mechanical treatment technology. Through a complex mechanical treatment, the spent $\mathrm{Li}$-ion batteries are converted to several marketable concentrates that can be used as raw material for other metallurgical processes [12].

Many studies in laboratory scale were reported using hydrometallurgical methods. $\mathrm{H}_{2} \mathrm{SO}_{4}, \mathrm{HCl}$ and $\mathrm{HNO}_{3}$ are often used as leaching agents to extract metals in the electrode powder. Generally, an additive-like hydrogen peroxide $\left(\mathrm{H}_{2} \mathrm{O}_{2}\right)$ is required to obtain the high dissolution efficiency. The temperature in the range of $50-85^{\circ} \mathrm{C}$ and acid concentrations in the range of $2-6 \mathrm{~mol} / \mathrm{L}$ were usually used with the solid-liquid ratio of $33: 125 \mathrm{~g} / \mathrm{L}$. For the material, which has a high $\mathrm{Al}$ content, a basic leaching with $\mathrm{NaOH}$ was performed to recycle Al. As a result, the leaching efficiency of investigated metals can reach $80 \%$ under certain leaching conditions. In term of solution purification, solvent extraction using PC88A and Cyanex272 is widely used. Cathode metals ( $\mathrm{Co}, \mathrm{Ni}$ and $\mathrm{Mn}$ ) can be selectively extracted under different conditions. On the other hand, the precipitation methods also play an important role, such as the Fe precipitation as goethite, Co hydroxide and Co oxalate precipitation. A co-precipitation method of $\mathrm{Co}, \mathrm{Ni}$ and $\mathrm{Mn}$ is published in the form of patent, in which the cathode material is synthesised from the co-precipitated metal salts [13]. Other methods, such as the crystallisation of Co sulphate $\left(\mathrm{CoSO}_{4}\right)$ and electrolytic depositions of Co, have also recovered Co successfully [14-22].

Based on the above results and discussion, the presented solutions cannot satisfy the new requirement in the aspect of environment and recycling efficiency, therefore an efficient and product-oriented recycling process is highly needed to handle the foreseeable large amount of spent automotive $\mathrm{Li}$-ion batteries. The motivations of this work are summarised below:

- Development of a recycling process, which is efficient, economical and environmental friendly.

- Recovery of the high-purity graphite as a marketable product under the optimised leaching conditions.

- Recovery of the cathode metal salt as a precursor using different precipitation methods.

\section{Design of Hydrometallurgical Recycling Process}

A possibility to recycle the high-purity graphite as a marketable product is reported in this paper. In the industrial process, the leaching residual of electrode powder is mainly an impure graphite, which can only be treated as industrial waste. However, in the newly developed process, the purity of graphite is highly increased through optimising the leaching conditions.

Another novelty is the recovery of cathode metals avoiding separation of them. The traditional separation of $\mathrm{Co}$ and $\mathrm{Ni}$ metallurgy by solvent extraction is a very complicated and slow method. Moreover, the separated Co and $\mathrm{Ni}$ salts are mixed again during the synthesis of the new cathode material, such as $\mathrm{LiCo}_{1 / 3} \mathrm{Ni}_{1 / 3} \mathrm{Mn}_{1 / 3} \mathrm{O}_{2}$. Instead of separating $\mathrm{Co}$ and $\mathrm{Ni}$, a new method is designed to precipitate cathode metals together. The obtained salts could serve as the precursor for synthesis of new cathode material.

The designed highly efficient hydrometallurgical recycling process is shown in Fig. 1. In the leaching step, two main objectives are set. One is to dissolve all the metals with a high efficiency and obtain graphite with high purity by the filtration. The other is to discover the optimum leaching conditions. Subsequently, $\mathrm{Cu}, \mathrm{Al}$ and $\mathrm{Fe}$ are recovered in the solution-refining step. The cementation process is firstly operated to recover $\mathrm{Cu}$. Secondly, the $\mathrm{NaOH}$ and $\mathrm{H}_{2} \mathrm{O}_{2}$ are added to adjust the $\mathrm{pH}$ of the solution and oxidise the $\mathrm{Fe}^{2+}$ to $\mathrm{Fe}^{3+}$ simultaneously. $\mathrm{Al}$ and $\mathrm{Fe}$ hydroxides are precipitated from the solution with an optimum $\mathrm{pH}$ value. The co-precipitation of other metals should be minimised under the optimum conditions.

In the following step, cathode metals $(\mathrm{Co}, \mathrm{Ni}$ and $\mathrm{Mn})$ are recovered by hydroxide, carbonate and sulphide precipitation, respectively. The obtained $\mathrm{Li}$ solution after 


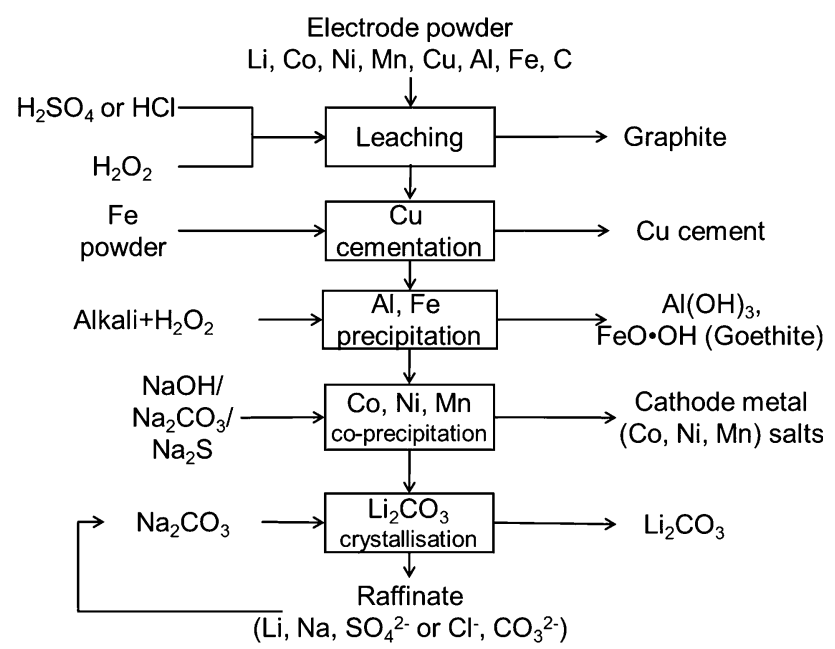

Fig. 1 The suggested hydrometallurgical recycling process

filtration is ready for $\mathrm{Li}_{2} \mathrm{CO}_{3}$ crystallisation through adding $\mathrm{Na}_{2} \mathrm{CO}_{3}$ solution at $95{ }^{\circ} \mathrm{C}$. To make the close loop of $\mathrm{Li}$, the $\mathrm{Li}$ containing raffinate is fed back to $\mathrm{Li}_{2} \mathrm{CO}_{3}$ crystallisation step.

\section{Theory of Applied Hydrometallurgical Processes}

\section{Leaching}

The sulphuric acid $\left(\mathrm{H}_{2} \mathrm{SO}_{4}\right)$ and hydrochloric acid $(\mathrm{HCl})$ are chosen as acid leaching agents in this paper. The leaching reaction for $\mathrm{LiCoO}_{2}$ at the presence of hydrogen peroxide $\left(\mathrm{H}_{2} \mathrm{O}_{2}\right)$ in sulphuric acid $\left(\mathrm{H}_{2} \mathrm{SO}_{4}\right)$ is as follows [21]:

$$
\begin{aligned}
& 2 \mathrm{LiCoO}_{2(\mathrm{~s})}+3 \mathrm{H}_{2} \mathrm{SO}_{4}+\mathrm{H}_{2} \mathrm{O}_{2} \\
& \quad \rightarrow \mathrm{Li}_{2} \mathrm{SO}_{4}+2 \mathrm{CoSO}_{4}+4 \mathrm{H}_{2} \mathrm{O}+\mathrm{O}_{2(\mathrm{~g})}
\end{aligned}
$$

The dissolution of $\mathrm{LiCoO}_{2}$ involves the reduction of $\mathrm{Co}^{3+}$ in the solid species to $\mathrm{Co}^{2+}$ in the aqueous phase. Similarly, the reactions of $\mathrm{LiNiO}_{2}$ and $\mathrm{LiMnO}_{2}$ are consistent with the above reaction. In addition, $\mathrm{H}_{2} \mathrm{O}_{2}$ is employed to oxidise the metallic $\mathrm{Cu}$ to $\mathrm{Cu}^{2+}$ ions. The chemical reaction between $\mathrm{H}_{2} \mathrm{O}_{2}$ and $\mathrm{Cu}$ is as follows:

$\mathrm{Cu}_{(\mathrm{s})}+\mathrm{H}_{2} \mathrm{SO}_{4}+\mathrm{H}_{2} \mathrm{O}_{2} \rightarrow \mathrm{CuSO}_{4}+2 \mathrm{H}_{2} \mathrm{O}$

\section{$\mathrm{Cu}$ Cementation}

$\mathrm{Cu}$ cementation with $\mathrm{Fe}$ is in extensive use in the hydrometallurgy. In principle, the ignoble metals can reduce the noble metal ions according to the electromotive force (EMF) series. The larger the voltage gap between the two half-cell reactions, the higher is the driving force for the reaction. In the case of the $\mathrm{Cu}$ cementation with $\mathrm{Fe}$ powder, the reaction is written below [23]:
$\mathrm{Fe}_{(\mathrm{s})}+\mathrm{Cu}^{2+} \rightarrow \mathrm{Fe}^{2+}+\mathrm{Cu}_{(\mathrm{s})}$

The $\mathrm{Cu}$ cementation mechanism can be described using the first-order reaction kinetic as follows [23, 24]:

$\frac{\mathrm{d}\left[\mathrm{Cu}^{2+}\right]}{\mathrm{dt}}=-\mathrm{k}\left[\mathrm{Cu}^{2+}\right]$,

where $\left[\mathrm{Cu}^{2+}\right]$ is the $\mathrm{Cu}$ concentration, $\mathrm{k}$ is the rate constant and $\mathrm{t}$ is the time.

By separation of variables and integration of the concentration and time, the result in a logarithmic relationship between the ion concentration and the time is as follows:

$\ln \frac{\left[\mathrm{Cu}^{2+}\right]}{\left[\mathrm{Cu}^{2+}\right]_{0}}=-\mathrm{k} * \mathrm{t}$.

The reaction rate constants $(\mathrm{k})$ for different temperatures can be determined, which allow a determination of the Arrhenius activation energy in the following reaction:

$k=A^{*} e^{-E_{\mathrm{A}} / \mathrm{RT}}$,

where $k$ is the rate constant, $E_{\mathrm{A}}$ is the activation energy $(\mathrm{J} / \mathrm{mol}), R=8.314 \mathrm{~J} * \mathrm{~K}^{-1} * \mathrm{~mol}^{-1}$ is the gas constant, $\mathrm{T}$ is the temperature $(\mathrm{K})$ and $\mathrm{A}$ is the stoichiometric coefficient

Taking the logarithm of Eq. 6, a linear relationship between the rate constants $(k)$ and $1 / T$ is obtained. However, a plot to $1000 / \mathrm{T}$ is frequently selected since the values of the $x$ axis are more manageable. Finally, the activation energy $\left(E_{\mathrm{A}}\right)$ can be calculated from the slope of this straight line. The equation is then as follows:

$\ln k=-\frac{E_{\mathrm{A}}}{R} * \frac{1000}{\mathrm{~T}}+\ln A$

\section{Experimental}

\section{Pre-treatment of Spent Automotive Li-ion Batteries}

Different from portable Li-ion batteries, the automotive Li-ion batteries must be dismantled at the beginning because of the large size and weight. The industrial partner has gathered the samples of spent $\mathrm{Li}$-ion automotive batteries from the manufactures. Figure 2 has shown the procedure of pre-treatment. The steel casing, $\mathrm{Cu}$ cables, plastics and electrical components (PCB) were manually separated from the cells in the dismantling step. In the following vacuum-thermal deactivation step, the battery cells were treated under thermal and vacuum conditions to deactivate the cells and vaporise the electrolyte. In an inductive heating vacuum furnace, the pressure of the furnace was decreased from 1 bar to 100 mbar. After that, the temperature was increased to $500{ }^{\circ} \mathrm{C}$ slowly. At this temperature, the volatile components like organics, halides and cracking products would evaporate and leave the cell 


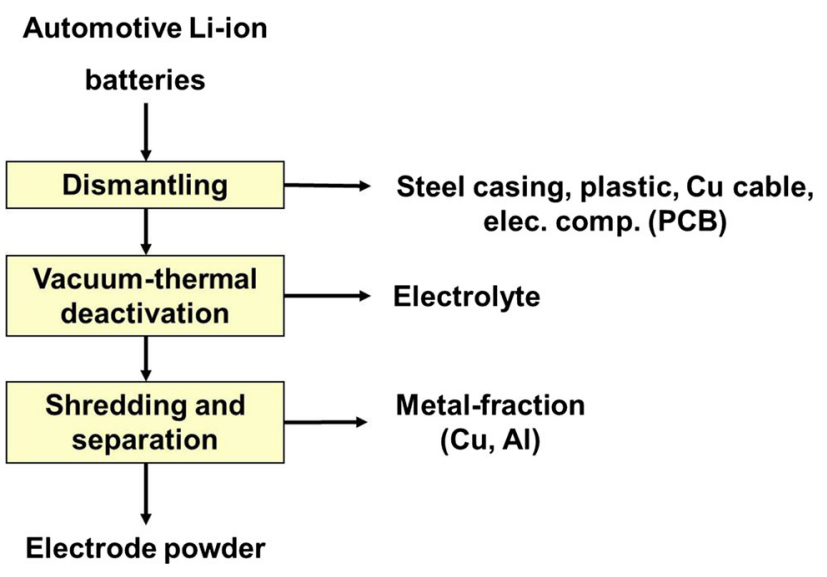

Fig. 2 Pre-treatment of spent automotive Li-ion batteries

through a pressure vent and were recovered in a condenser. After the vacuum-thermal treatment, the deactivated cells were granulated and sieved. By this way, the $\mathrm{Cu}$ and $\mathrm{Al}$ foils were separated from electrode powder. At last, the electrode powder was collected and applied as the raw material for leaching in the hydrometallurgical process.

\section{Characterisation of the Electrode Powder}

The chemical composition of the electrode powder is assayed by ICP-OES method and shown in Table 1. The contents of $\mathrm{Co}$ and $\mathrm{Ni}$ are about 22 and $9.9 \%$, respectively. $\mathrm{Al}, \mathrm{Fe}, \mathrm{Mn}$ and $\mathrm{Cu}$ have low contents, which are in the range of $0.2-1.18 \%$. However, $\mathrm{Li}$ content is about $3.7 \%$ in the raw material. It has a very small variability in many kinds of electrode powder. As the main component in the powder, graphite takes more than one-third of the whole weight of powder.

Particle size analysis was performed by Sympatec's laser diffraction sensor HELOS. The particle size distribution of three random samples in terms of cumulative passing percentage versus size in microns was assayed. In the result, about $10 \%$ of the particles are smaller than $5 \mu \mathrm{m}$ and $90 \%$ of the particles are smaller than $60 \mu \mathrm{m}$. The $d_{50}$ equals to $20 \mu \mathrm{m}$.

Furthermore, the SEM photograph of the electrode powder is shown in Fig. 3, and the graphite particles, metallic particles and metal compounds are mixed homogeneously. As the dismantled cells are completely crushed

Table 1 Elemental composition for electrode powder sample in wt\%

\begin{tabular}{lllllllll}
\hline Components & $\mathrm{Al}$ & $\mathrm{Co}$ & $\mathrm{Cu}$ & $\mathrm{Li}$ & $\mathrm{Ni}$ & $\mathrm{Mn}$ & $\mathrm{Fe}$ & $\mathrm{C}$ \\
\hline [wt\%] & 1.18 & 22.13 & 0.92 & 3.67 & 9.92 & 0.21 & 0.31 & 36.13
\end{tabular}

and sieved in the pre-treatment process, the shape of particles is relatively inerratic.

\section{Laboratory Tests}

The electrode powder obtained by pre-treatment was used in the leaching tests. The effects of parameters, such as temperature $\left(25-70{ }^{\circ} \mathrm{C}\right)$, hydrogen peroxide concentration $(0-100 \mathrm{~g} / \mathrm{L})$ and sulphuric acid concentration $(2-4 \mathrm{~mol} / \mathrm{L})$, were investigated with $100 \mathrm{~g} / \mathrm{L}$ solid liquid ratio and 75 min retention time. Since $\mathrm{H}_{2} \mathrm{O}_{2}$ can easily decompose, $50 \%$ of the required amount of $\mathrm{H}_{2} \mathrm{O}_{2}$ was added at the beginning, and the rest of $\mathrm{H}_{2} \mathrm{O}_{2}$ was added continuously throughout the whole retention time using a burette. When the leaching process was finished, the leaching solution was filtered using a vacuum filter. The filtered graphite was washed with deionized water to remove the acid traces and dried in an oven at $90{ }^{\circ} \mathrm{C}$ for $10 \mathrm{~h}$ before it was weighed. Additionally, the verification experiments were carried out in sulphuric acid ( $2 \mathrm{~mol} / \mathrm{L})$ and hydrochloric acid $(4 \mathrm{~mol} /$ $\mathrm{L})$ at the presence or absence of hydrogen peroxide $(50 \mathrm{~g} /$ L) with $100 \mathrm{~g} / \mathrm{L}$ solid liquid ratio and $120 \mathrm{~min}$ retention time. The photography of filtered graphite was characterised by the SEM method.

In $\mathrm{Cu}$ cementation tests, a metallic $\mathrm{Fe}$ powder with particle size "200 Mesh" was used to reduce $\mathrm{Cu}^{2+}$ in the leaching solution. Firstly, a $300 \mathrm{~mL}$ of solution was poured into a $600-\mathrm{mL}$ beaker that was placed on the heating plate. Following, the solution was stirred at 150 RPM and heated up to the target temperatures $\left(25,40,60\right.$ and $\left.80{ }^{\circ} \mathrm{C}\right)$ before adding the powder.

For the metal hydroxide and carbonate precipitation tests, titration experiment with a $400 \mathrm{~mL}$ of initial solution was instructed by adding $\mathrm{NaOH}$ solution $(200 \mathrm{~g} / \mathrm{L})$ and $\mathrm{Na}_{2} \mathrm{CO}_{3}$ solution $(200 \mathrm{~g} / \mathrm{L})$ drop by drop using a $50-\mathrm{mL}$ burette at $40{ }^{\circ} \mathrm{C}$. The $\mathrm{pH}$ was increased from $\mathrm{pH} 1$ to 10 during the experiment. Solution samples were taken using a $15-\mathrm{mL}$ pipette at specific $\mathrm{pH}$ levels. For the metal sulphide precipitation, experiment started by addition of a $\mathrm{Na}_{2} \mathrm{~S} \cdot 9 \mathrm{H}_{2} \mathrm{O}$ solution $(100 \mathrm{~g} / \mathrm{L})$ using a $50-\mathrm{mL}$ burette. The concentration of sulphide ions in solution was increased from 0 to $10.5 \mathrm{~g} / \mathrm{L}$. Figure 4 has shown the filtration of cathode metal salts with the three methods.

$\mathrm{Li}_{2} \mathrm{CO}_{3}$ crystallisation by titration with $\mathrm{Na}_{2} \mathrm{CO}_{3}(200 \mathrm{~g} /$ L) was implemented. $500 \mathrm{~mL}$ of initial solution generating from metal hydroxide precipitation was evaporated at $95{ }^{\circ} \mathrm{C}$ within $3 \mathrm{~h}$ until the volume of solution reduced to about $100 \mathrm{~mL}$. At this time, a solution of $\mathrm{Na}_{2} \mathrm{CO}_{3}(200 \mathrm{~g} /$ L) was titrated into the solution until attaining 1.2 times (stoichiometric equivalent) the moles of $\mathrm{Li}$ ions. After $10 \mathrm{~min}$, the crystallised white powder was filtered and prepared for chemical assay. 

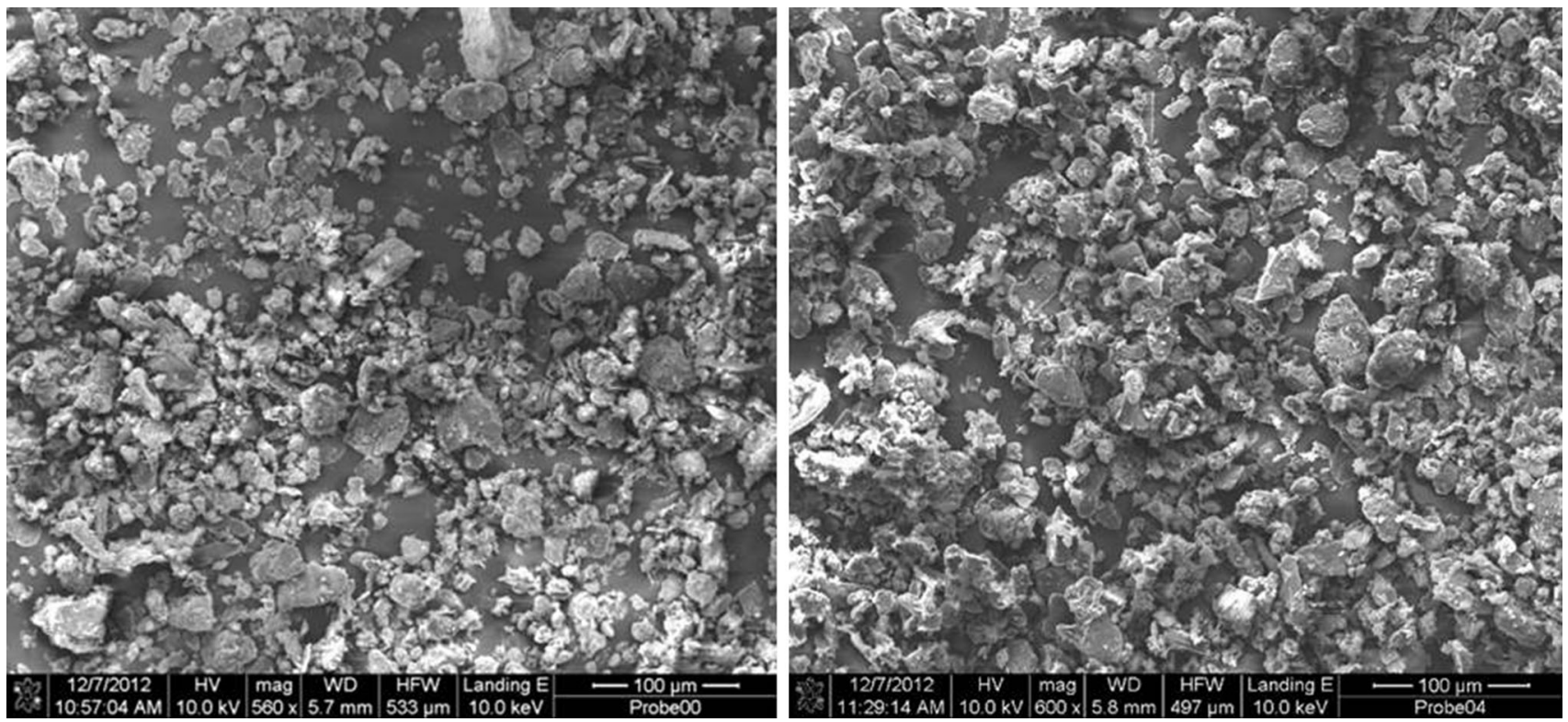

Fig. 3 Low-magnification SEM photograph of electrode powder (left) and graphite after leaching (right)

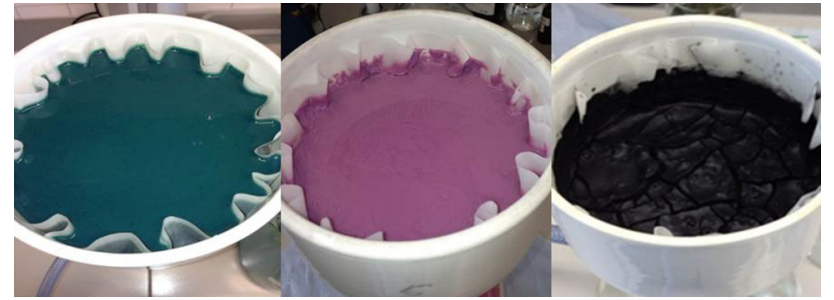

Fig. 4 Formation and filtration of $\mathrm{Co}, \mathrm{Ni}$ and $\mathrm{Mn}$ precipitates (from left to right: metal hydroxide, metal carbonate and metal sulphide)

\section{Results and Discussion}

\section{Leaching}

\section{Effect of Temperature}

The extraction rates of $\mathrm{Li}, \mathrm{Co}, \mathrm{Cu}, \mathrm{Ni}, \mathrm{Al}, \mathrm{Fe}$ and $\mathrm{Mn}$ in the leaching process at different temperatures are shown in Fig. 5. Apparently, Ni dissolution increases from 50 to $97 \%(\Delta=47 \%)$ as the temperature increases from 22 to $70{ }^{\circ} \mathrm{C}$. Similarly, the extraction rate of $\mathrm{Fe}$ has also increased a lot with increasing the temperature. About $5 \%$ increment for the Co extraction rate is found in the same range of temperature.

However, the effect of the temperature on other metals is not obvious. The extraction rates of $\mathrm{Li}, \mathrm{Al}$ and $\mathrm{Cu}$ are larger than $88 \%$ at $22{ }^{\circ} \mathrm{C}$. As the temperature increases from 22 to $70{ }^{\circ} \mathrm{C}$, the dissolved Li changes gradually from 95 to $98.5 \%(\Delta=3.5 \%)$, meanwhile the extraction rate of $\mathrm{Cu}$ increases from 96 to $98.6 \%(\Delta=2.6 \%)$. Almost

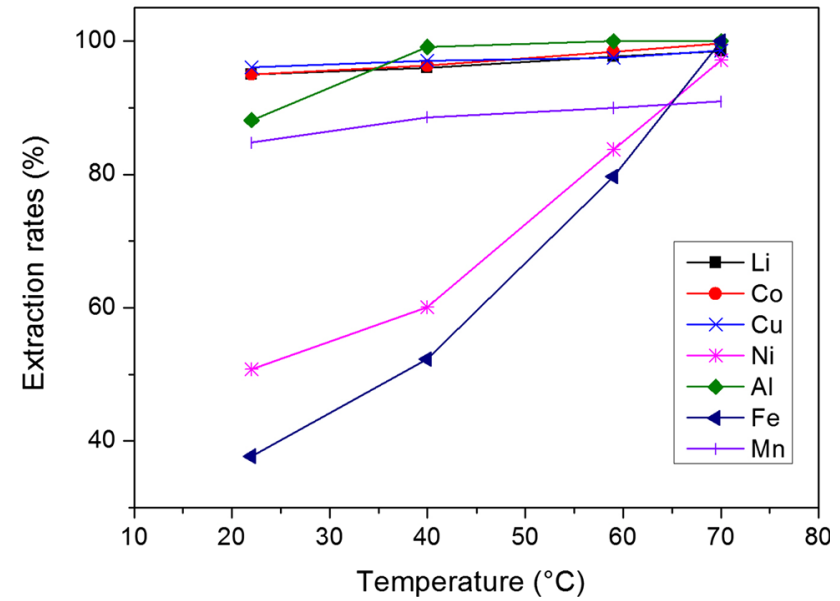

Fig. 5 Metal extraction by temperature for $\mathrm{Li}, \mathrm{Co}, \mathrm{Cu}, \mathrm{Ni}, \mathrm{Al}, \mathrm{Fe}$ and $\mathrm{Mn} \quad\left(\mathrm{S} / \mathrm{L}=100 \mathrm{~g} / \mathrm{L}, \quad\left[\mathrm{H}_{2} \mathrm{SO}_{4}\right]=2 \mathrm{~mol} / \mathrm{L}, \quad\left[\mathrm{H}_{2} \mathrm{O}_{2}\right]=50 \mathrm{~g} / \mathrm{L}\right.$, time $=1.25 \mathrm{~h})$

$100 \%$ of $\mathrm{Al}$ is dissolved since $60{ }^{\circ} \mathrm{C}$. The $\mathrm{Mn}$ has an average extraction rate of $85 \%$ in all trials.

Accordingly, the optimum temperature of the leaching is $70{ }^{\circ} \mathrm{C}$ among the 4 tested temperatures, since it exhibits the highest metal extraction rates for almost all the metals.

\section{Effect of Hydrogen Peroxide $\left(\mathrm{H}_{2} \mathrm{O}_{2}\right)$ Concentration}

The extraction rates of the $\mathrm{Li}, \mathrm{Co}, \mathrm{Ni}, \mathrm{Cu}, \mathrm{Al}, \mathrm{Fe}$ and $\mathrm{Mn}$ are shown in Fig. 6 at different $\mathrm{H}_{2} \mathrm{O}_{2}$ concentrations of 0 , $25,50,75$ and $100 \mathrm{~g} / \mathrm{L}$. The strongest response to the $\mathrm{H}_{2} \mathrm{O}_{2}$ addition is revealed on the $\mathrm{Cu}$ extraction rate, which goes from $7.9 \%$ sharply up to $96.6 \%(\Delta=88.7 \%)$ as the 


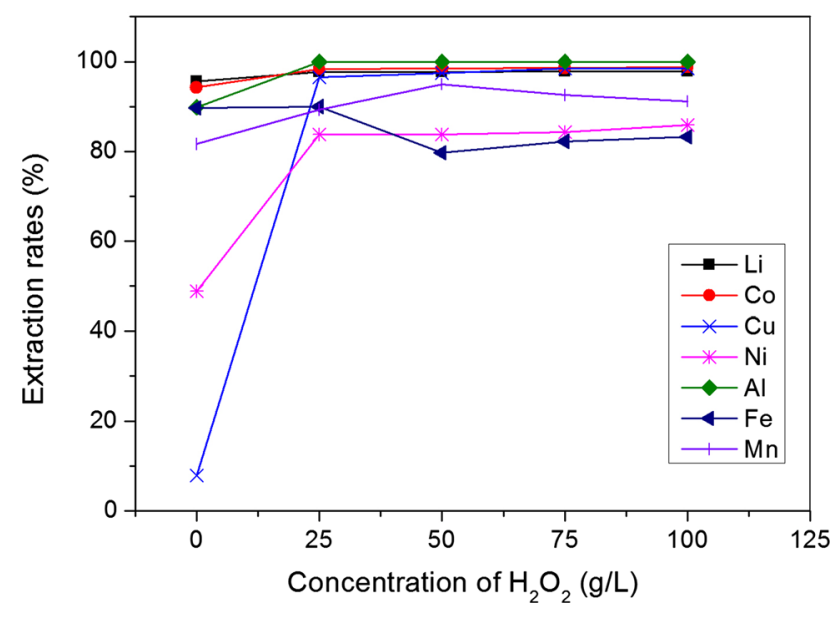

Fig. 6 Metal extraction by $\mathrm{H}_{2} \mathrm{O}_{2}$ concentration for $\mathrm{Li}, \mathrm{Co}, \mathrm{Cu}, \mathrm{Ni}, \mathrm{Al}$, $\mathrm{Fe}$ and $\mathrm{Mn}\left(\mathrm{S} / \mathrm{L}=100 \mathrm{~g} / \mathrm{L}, \quad\left[\mathrm{H}_{2} \mathrm{SO}_{4}\right]=2 \mathrm{~mol} / \mathrm{L}, \quad \mathrm{T}=59^{\circ} \mathrm{C}\right.$, time $=1.25 \mathrm{~h}$ )

$\mathrm{H}_{2} \mathrm{O}_{2}$ concentration increases from 0 to $25 \mathrm{~g} / \mathrm{L}$. It can be explained by the noble nature of metallic $\mathrm{Cu}$ in the electrode powder; hence, a strong oxidising reagent is needed to dissolve $\mathrm{Cu}$. The extraction rate of $\mathrm{Ni}$ rises from 48.9 to $83.7 \%(\Delta=34.8 \%)$ as the $\mathrm{H}_{2} \mathrm{O}_{2}$ concentration increases from 0 to $25 \mathrm{~g} / \mathrm{L}$. However, when the $\mathrm{H}_{2} \mathrm{O}_{2}$ concentration is further increased to $100 \mathrm{~g} / \mathrm{L}$, the extraction rates of $\mathrm{Cu}$ and Ni increase only by $2 \%$.

On the other hand, $\mathrm{Li}, \mathrm{Co}, \mathrm{Al}$ and $\mathrm{Mn}$ have shown insignificant improvement of the extraction rates with the addition of $\mathrm{H}_{2} \mathrm{O}_{2}$. By increasing the $\mathrm{H}_{2} \mathrm{O}_{2}$ concentration from 0 to $25 \mathrm{~g} / \mathrm{L}$, the extraction rate of $\mathrm{Li}$ increases from 95.7 to $97.7 \%(\Delta=2 \%)$ and Co extraction rate rises from 94.3 to $98.4 \%(\Delta=4.1 \%)$. Furthermore, the extraction of $\mathrm{Al}$ and $\mathrm{Mn}$ has increased by 10.2 and $8.4 \%$, respectively. The extraction of metallic $\mathrm{Fe}$ is not affected by the $\mathrm{H}_{2} \mathrm{O}_{2}$; however, it is very helpful for the oxidation of bivalent iron. According to the above results, it can be concluded that $25 \mathrm{~g} / \mathrm{L}$ of $\mathrm{H}_{2} \mathrm{O}_{2}$ is efficient for $\mathrm{Cu}$ and $\mathrm{Ni}$ leaching. Nevertheless, $50 \mathrm{~g} / \mathrm{L}$ of $\mathrm{H}_{2} \mathrm{O}_{2}$ is recommended to ensure a high extraction rate for all metals.

\section{Effect of Sulphuric Acid Concentration}

The effects of the sulphuric acid concentrations $(1,1.33,2$ and $4 \mathrm{~mol} / \mathrm{L}$ ) on the extraction rates of $\mathrm{Li}, \mathrm{Co}, \mathrm{Ni}, \mathrm{Cu}, \mathrm{Al}$, $\mathrm{Fe}$ and $\mathrm{Mn}$ are shown in Fig. 7. An increment of Ni extraction $(\Delta=21.4 \%)$ is observed when the concentration of $\mathrm{H}_{2} \mathrm{SO}_{4}$ acid rises from 1 to $4 \mathrm{~mol} / \mathrm{L}$. Similarly, the extraction of $\mathrm{Fe}$ was also increased from $41.9 \%(1 \mathrm{~mol} / \mathrm{L})$ to $88.1 \%(4 \mathrm{~mol} / \mathrm{L})$.

It can be seen that the effect of sulphuric acid concentration on dissolution of $\mathrm{Li}, \mathrm{Co}, \mathrm{Cu}, \mathrm{Mn}$ and $\mathrm{Al}$ is not obvious. $\mathrm{Cu}$ extraction rate is kept at a high level and

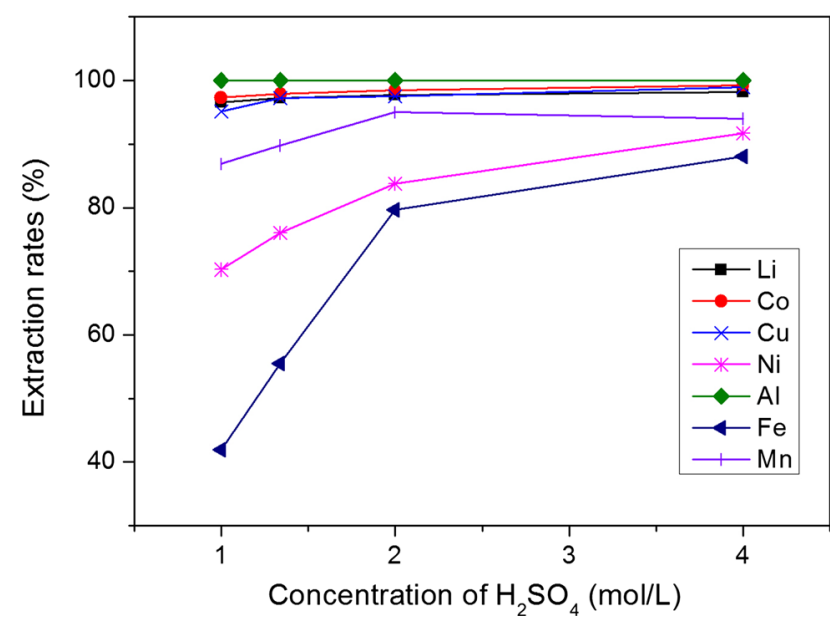

Fig. 7 Metal extraction by $\mathrm{H}_{2} \mathrm{SO}_{4}$ concentration for $\mathrm{Li}, \mathrm{Co}, \mathrm{Cu}, \mathrm{Ni}$, $\mathrm{Al}, \mathrm{Fe}$ and $\mathrm{Mn}\left(\mathrm{S} / \mathrm{L}=100 \mathrm{~g} / \mathrm{L},\left[\mathrm{H}_{2} \mathrm{O}_{2}\right]=50 \mathrm{~g} / \mathrm{L}, \mathrm{T}=59^{\circ} \mathrm{C}\right.$, time $=1.25 \mathrm{~h}$ )

increases by $4.1 \%$ as the acid concentration increases from 1 to $4 \mathrm{~mol} / \mathrm{L}$. The extraction rates of $\mathrm{Li}$ and Co increase by 1.7 and $2 \%$, respectively. The extraction rate of $\mathrm{Mn}$ fluctuates at $90 \%$.

\section{Verification Tests of Leaching}

After investigating the effects of different parameters, $80{ }^{\circ} \mathrm{C}, 50 \mathrm{~g} / \mathrm{L}$ of $\mathrm{H}_{2} \mathrm{O}_{2}, 2 \mathrm{~mol} / \mathrm{L}$ of sulphuric acid or $4 \mathrm{~mol} /$ $\mathrm{L}$ of hydrochloric acid are recommended for the subsequent verification leaching. Leaching experiments with different acids $\left(2 \mathrm{~mol} / \mathrm{L} \mathrm{H}_{2} \mathrm{SO}_{4}\right.$ and $\left.4 \mathrm{~mol} / \mathrm{L} \mathrm{HCl}\right)$ and different concentrations of additive reagent $(0$ and $50 \mathrm{~g} / \mathrm{L}$ $\mathrm{H}_{2} \mathrm{O}_{2}$ ) were carried out at $80{ }^{\circ} \mathrm{C}$ with solid liquid ratio of $100 \mathrm{~g} / \mathrm{L}$. The retention time was extended to $2 \mathrm{~h}$ to ensure a high leaching efficiency.

The extraction rates of $\mathrm{Co}, \mathrm{Ni}, \mathrm{Li}, \mathrm{Cu}, \mathrm{Al}, \mathrm{Fe}$ and $\mathrm{Mn}$ are shown in Fig. 8. The extraction rates of Co in the four trails are all higher than $99.9 \%$. Similarly, the extraction rates of $\mathrm{Li}$ have reached $99.3 \%$. At the presence of $\mathrm{H}_{2} \mathrm{O}_{2}(50 \mathrm{~g} / \mathrm{L})$, the $\mathrm{Cu}$ dissolution is higher than $99.9 \%$ in both $\mathrm{HCl}$ and $\mathrm{H}_{2} \mathrm{SO}_{4}$ acids. However, at the absence of $\mathrm{H}_{2} \mathrm{O}_{2}$, the extraction rate of $\mathrm{Cu}$ is only $73.2 \%$ in $\mathrm{H}_{2} \mathrm{SO}_{4}$ media and $87.1 \%$ in $\mathrm{HCl}$ media. On the other hand, the extraction of $\mathrm{Ni}$ mainly depends on the types of acid. $\mathrm{Ni}$ is easier dissolved in $\mathrm{HCl}$ than in $\mathrm{H}_{2} \mathrm{SO}_{4}$. It has reached $99.9 \%$ in $\mathrm{HCl}$ regardless of $\mathrm{H}_{2} \mathrm{O}_{2}$; yet, $98.6 \%$ of $\mathrm{Ni}$ is leached in $\mathrm{H}_{2} \mathrm{SO}_{4}$ media at the presence of $\mathrm{H}_{2} \mathrm{O}_{2}$, and it is even lowered to $97.9 \%$ at the absence of $\mathrm{H}_{2} \mathrm{O}_{2}$. The extraction rates of $\mathrm{Mn}$ and $\mathrm{Al}$ in all trails are over 99 and $98 \%$, respectively. The $\mathrm{Fe}$ has a relative wide extraction range $(94.8 \%$ in " $\mathrm{HCl}+\mathrm{H}_{2} \mathrm{O}_{2}$ " and $99.8 \%$ in " $\mathrm{H}_{2} \mathrm{SO}_{4}+\mathrm{H}_{2} \mathrm{O}_{2}$ "). Considering the very low composition of $\mathrm{Fe}(0.31 \%)$, this extraction rate can be accepted. As a summing up, both 


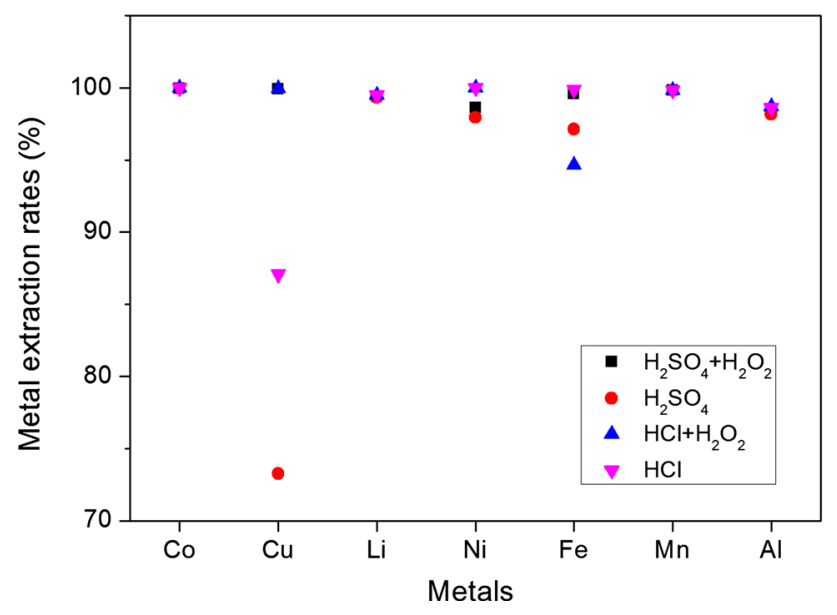

Fig. 8 Extraction rates of $\mathrm{Li}, \mathrm{Co}, \mathrm{Cu}, \mathrm{Ni}, \mathrm{Al}, \mathrm{Fe}$ and $\mathrm{Mn}$ $\left([\mathrm{HCl}]=4 \mathrm{~mol} / \mathrm{L}\right.$ or $\left[\mathrm{H}_{2} \mathrm{SO}_{4}\right]=2 \mathrm{~mol} / \mathrm{L},\left[\mathrm{H}_{2} \mathrm{O}_{2}\right]=0 \mathrm{~g} / \mathrm{L}$ or $50 \mathrm{~g} /$ $\mathrm{L}, \mathrm{T}=80{ }^{\circ} \mathrm{C}, \mathrm{S} / \mathrm{L}=100 \mathrm{~g} / \mathrm{L}, t=2 \mathrm{~h}$ )

acids are able to leach $\mathrm{Al}, \mathrm{Li}, \mathrm{Fe}, \mathrm{Mn}$ and $\mathrm{Co}$ efficiently. The $\mathrm{Ni}$ and $\mathrm{Cu}$ are easier be leached in $\mathrm{HCl}$ than $\mathrm{H}_{2} \mathrm{SO}_{4}$. The adding of $\mathrm{H}_{2} \mathrm{O}_{2}$ in acid significantly increases the dissolution of $\mathrm{Cu}$.

In addition, the chemical compositions of the filtered graphite are assayed and shown in Table 2. The carbon contents in the residues are above $99.8 \%$ after leaching at the presence of $\mathrm{H}_{2} \mathrm{O}_{2}$ in both acids. However, in the experiments at the absence of $\mathrm{H}_{2} \mathrm{O}_{2}$, the purities of graphite are only $98.5 \%$ in sulphuric acid and $99.5 \%$ in hydrochloric acid, respectively. From the SEM photographs of filtered graphite (from trail " $\mathrm{HCl}+\mathrm{H}_{2} \mathrm{O}_{2}$ ") comparing with the electrode powder in Fig. 3, it can be observed that the shape and the size of graphite are not changed before and after leaching. The fine morphology and high purity ensure the feasibility of reutilisation as the battery-level graphite.

\section{Cu Cementation}

The $\mathrm{Cu}$ contents in solution by time at different temperatures are shown in Fig. 9. Apparently, the concentrations of $\mathrm{Cu}$ in solution decrease sharply within the first $5 \mathrm{~min}$. Nearly, all $\mathrm{Cu}$ ions are reduced in $40 \mathrm{~min}$. It is clear that the test at room temperature $\left(25^{\circ} \mathrm{C}\right)$ shows the slowest cementation kinetic. $\mathrm{Cu}$ precipitates faster at higher temperature. On the other hand, the oxidised $\mathrm{Fe}$ has also demonstrated the reaction kinetics, as shown in Fig. 10. It is found that $\mathrm{Fe}$ powder dissolves fast at high temperature, especially at $80{ }^{\circ} \mathrm{C}$.

Additionally, the activation energy of $\mathrm{Cu}$ cementation is calculated based on the Arrhenius plot. According to Eq. 5, the rate constants $(\mathrm{k})$ at different temperatures are obtained from the slope of the regression line. Following, an Arrhenius plot of $\ln (\mathrm{k})$ to $1000 / \mathrm{T}$ is shown in Fig. 11. At last, the activation energy $\left(E_{\mathrm{A}}\right)$ is computed from the slope of this straight line based on Eq. 7 .

$E_{\mathrm{A}}=1.5539 \times 8.314 \frac{\mathrm{J}}{\mathrm{K} * \mathrm{~mol}} \times 1000 \mathrm{~K}=12.92 \mathrm{~kJ} / \mathrm{mol}$

The final calculated activation energy is $12.92 \mathrm{~kJ} / \mathrm{mol}$ as shown in Eq. 8, which is basically consistent with other researchers, such as El-Batouti $(25-39 \mathrm{~kJ} / \mathrm{mol})$ and Miller $(36 \mathrm{~kJ} / \mathrm{mol})$. It indicates that the reaction of $\mathrm{Cu}$ cementation by $\mathrm{Fe}$ is mainly controlled by the boundary layer diffusion. Therefore, the high temperature is favoured for the $\mathrm{Cu}$ cementation; hence, $60{ }^{\circ} \mathrm{C}$ is efficient among the four tested temperatures and avoids too much dissolution of $\mathrm{Fe}[24,25]$.

\section{Metal Hydroxide Precipitation (Fe, Al and Cathode Metals)}

After the removal of $\mathrm{Cu}$, metal hydroxide precipitation is implemented to precipitate $\mathrm{Fe}$ and $\mathrm{Al}$, afterwards, $\mathrm{Co}$, Ni and $\mathrm{Mn}$. In principle, $\mathrm{Fe}$ is precipitated in the form of goethite $(\alpha-\mathrm{FeO} \cdot \mathrm{OH})$ according to Eq. 9. The final concentration of $\mathrm{Fe}^{3+}$ in the solution is in general no more than $1 \mathrm{~g} / \mathrm{L}$. $\mathrm{Al}$ is precipitated as a metal hydroxide in Eq. 10 $[23,26]$.

$\mathrm{Fe}_{2}\left(\mathrm{SO}_{4}\right)_{3}+4 \mathrm{H}_{2} \mathrm{O} \rightarrow 2 \mathrm{FeO} \cdot \mathrm{OH}_{(\mathrm{s})}+3 \mathrm{H}_{2} \mathrm{SO}_{4}$

$\mathrm{Al}^{3+}+3 \mathrm{OH}^{-} \rightarrow \mathrm{Al}(\mathrm{OH})_{3}$

It should be stressed that the performance of precipitation is highly dependent on the $\mathrm{pH}$ value of the solution. The removal of $\mathrm{Fe}$ and $\mathrm{Al}$ is not complete when $\mathrm{pH}$ value is lower than the demanded value. On the other hand, $\mathrm{Co}, \mathrm{Ni}$ and $\mathrm{Mn}$ will co-precipitate when $\mathrm{pH}$ value is too high. Therefore, an optimum $\mathrm{pH}$ value is required to make sure

Table 2 Chemical composition of leaching residues $([\mathrm{HCl}]=4 \mathrm{~mol} / \mathrm{L}$, $\left[\mathrm{H}_{2} \mathrm{SO}_{4}\right]=2 \mathrm{~mol} / \mathrm{L}$, $\left[\mathrm{H}_{2} \mathrm{O}_{2}\right]=50 \mathrm{~g} / \mathrm{L}, \mathrm{T}=80{ }^{\circ} \mathrm{C}$, $\mathrm{S} / \mathrm{L}=100 \mathrm{~g} / \mathrm{L}, t=2 \mathrm{~h}$, agitation speed $=300$ RPM)

\begin{tabular}{lllllllll}
\hline Leaching conditions & $\begin{array}{l}\mathrm{Al} \\
\mathrm{ppm}\end{array}$ & $\begin{array}{l}\mathrm{Co} \\
\mathrm{ppm}\end{array}$ & $\begin{array}{l}\mathrm{Cu} \\
\mathrm{ppm}\end{array}$ & $\begin{array}{l}\mathrm{Fe} \\
\mathrm{ppm}\end{array}$ & $\begin{array}{l}\mathrm{Li} \\
\mathrm{ppm}\end{array}$ & $\begin{array}{l}\mathrm{Mn} \\
\mathrm{ppm}\end{array}$ & $\begin{array}{l}\mathrm{Ni} \\
\text { ppm }\end{array}$ & $\begin{array}{l}\mathrm{C} \\
(\%)\end{array}$ \\
\hline $\mathrm{H}_{2} \mathrm{SO}_{4}+\mathrm{H}_{2} \mathrm{O}_{2}, \mathrm{~T}=80{ }^{\circ} \mathrm{C}$ & 493 & $<10$ & $<10$ & 39 & 603 & $<10$ & 812 & 99.80 \\
$\mathrm{H}_{2} \mathrm{SO}_{4}, \mathrm{~T}=80{ }^{\circ} \mathrm{C}$ & 608 & 306 & $0.69 \%$ & 249 & 666 & $<10$ & $0.57 \%$ & 98.56 \\
$\mathrm{HCl}+\mathrm{H}_{2} \mathrm{O}_{2}, \mathrm{~T}=80{ }^{\circ} \mathrm{C}$ & 433 & $<10$ & $<10$ & 470 & 540 & $<10$ & $<10$ & 99.85 \\
$\mathrm{HCl}, \mathrm{T}=80{ }^{\circ} \mathrm{C}$ & 474 & $<10$ & $0.34 \%$ & $<10$ & 537 & $<10$ & $<10$ & 99.55 \\
\hline
\end{tabular}




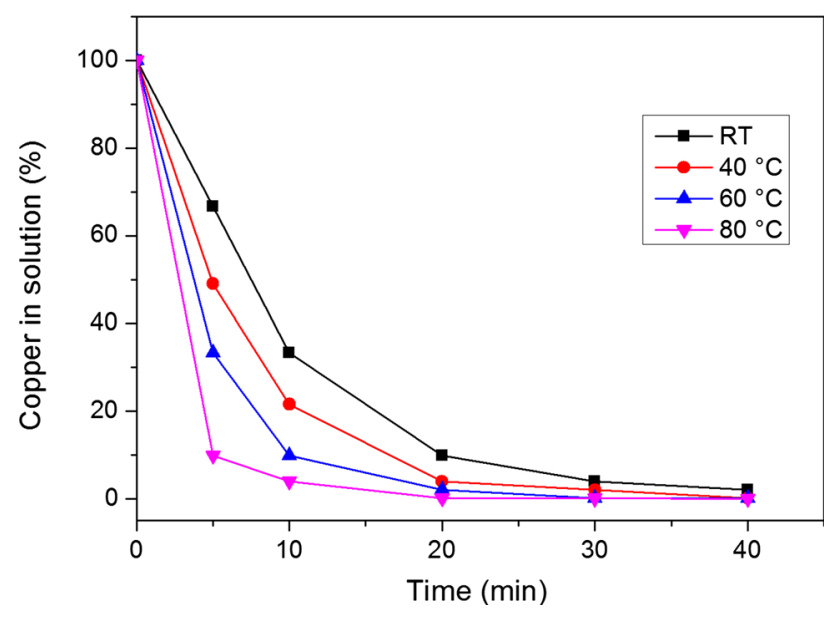

Fig. $9 \mathrm{Cu}$ in solution by time at different solution temperatures $(\mathrm{pH}=1.2)$

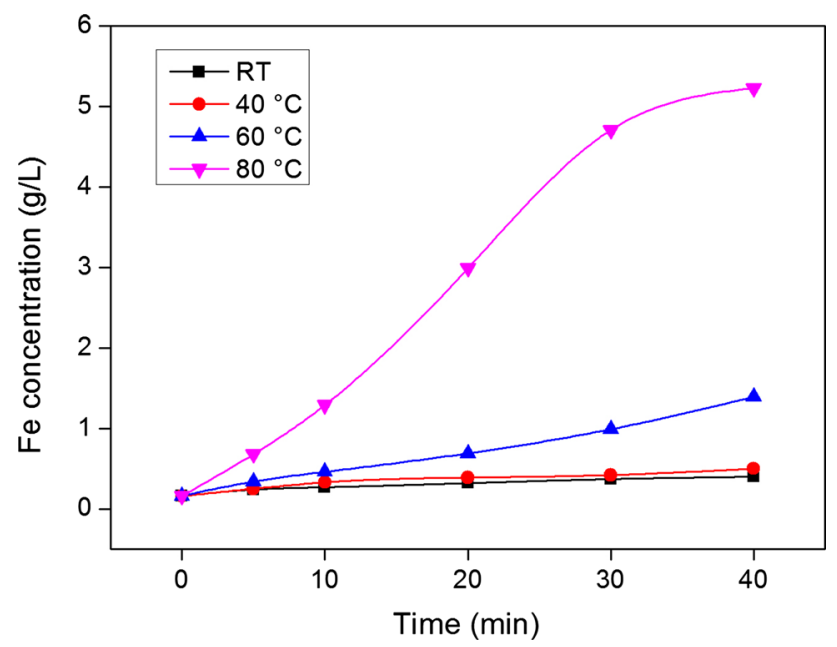

Fig. $10 \mathrm{Fe}$ in solution by time at different solution temperatures $(\mathrm{pH}=1.2)$

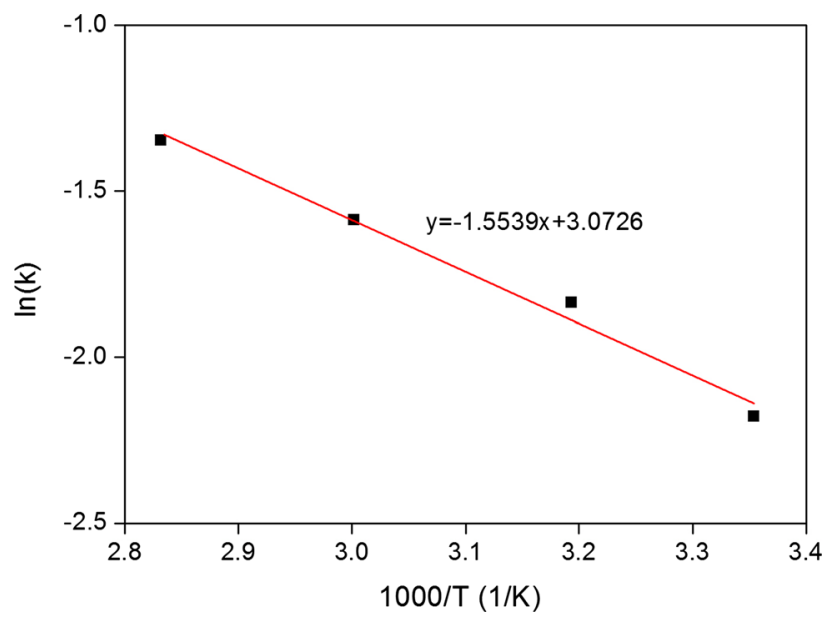

Fig. 11 Arrhenius plot of the experimental results

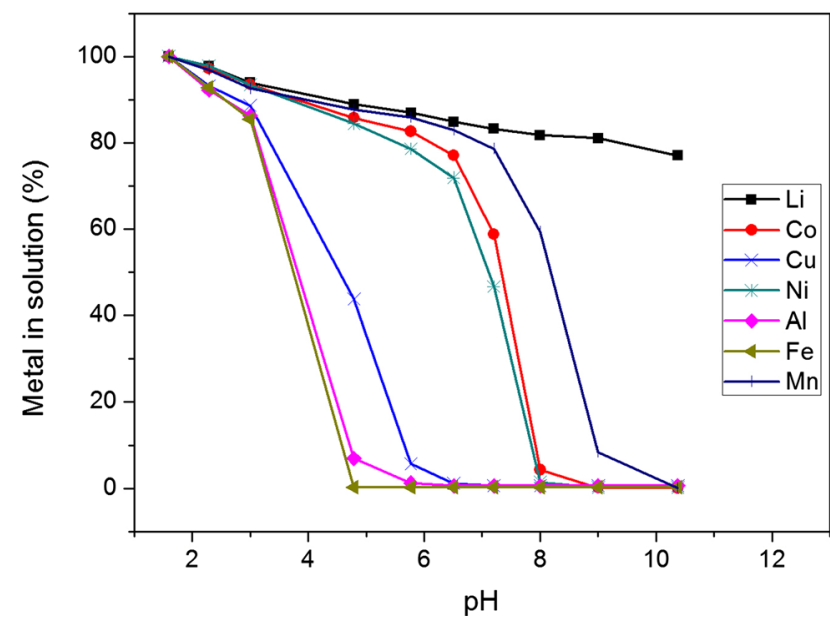

Fig. 12 Metal precipitation using $\mathrm{NaOH}$ solution

more removal of $\mathrm{Fe}$ and $\mathrm{Al}$ and simultaneously less loss of other valuable metals. Figure 12 shows the metal precipitation diagram at $40{ }^{\circ} \mathrm{C}$ by titration with $\mathrm{NaOH}$. The contents of $\mathrm{Fe}, \mathrm{Al}$ and $\mathrm{Cu}$ in the solution decrease rapidly from $\mathrm{pH} 2.3$ to $\mathrm{pH} 4.8$. Obviously, $\mathrm{Cu}$ precipitates less than $\mathrm{Fe}$ and $\mathrm{Al}$ at the same $\mathrm{pH}$ value. When $\mathrm{pH} 4.8$ is attained, $99.75 \%$ of $\mathrm{Fe}$ has already been precipitated, while $6.9 \%$ of $\mathrm{Al}$ and $43.8 \%$ of the $\mathrm{Cu}$ are still in solution. At the end of $\mathrm{Fe}$ and $\mathrm{Al}$ precipitation, the co-precipitation (loss) of Co and Ni has reached a relatively high level, which cannot be ignored. It has a high risk to lose the valuable $\mathrm{Co}$ and $\mathrm{Ni}$ metals in this step if the $\mathrm{pH}$ value is not concisely controlled. Hence, the optimum ending $\mathrm{pH}$ value should be 3.5-4 to ensure the sufficient removal of $\mathrm{Fe}$ and $\mathrm{Al}$ and also minimum loss of $\mathrm{Co}, \mathrm{Ni}$ and $\mathrm{Mn}$. Until pH 5.8, nearly all $\mathrm{Fe}, \mathrm{Al}$ and $\mathrm{Cu}$ are precipitated. The precipitation rates have reached $21.4 \%$ for $\mathrm{Ni}, 17.3 \%$ for $\mathrm{Co}$ and $14.1 \%$ for $\mathrm{Mn}$, respectively. At the same $\mathrm{pH}$ value, $\mathrm{Mn}$ presents a lower precipitation rate than $\mathrm{Co}$ and $\mathrm{Ni}$. At $\mathrm{pH} 8$, more than $90 \%$ of $\mathrm{Co}$ and $\mathrm{Ni}$ have been precipitated. However, $59 \%$ of $\mathrm{Mn}$ is still in solution. At $\mathrm{pH}$ 9, more than $99.8 \%$ of Co and Ni metals are removed from solution. Finally, $\mathrm{Mn}$ is completely ( $>99.9 \%$ ) removed from the solution at $\mathrm{pH}$ 10.37. In addition, $\mathrm{Li}$ in solution decreases by $20 \%$ at the end of the experiment because of the absorption.

\section{Metal Carbonate Precipitation}

The cathode metal precipitation by titration with $\mathrm{Na}_{2} \mathrm{CO}_{3}$ is presented in Fig. 13. From pH 2 to 3.5, the precipitation of $\mathrm{Fe}$ and $\mathrm{Al}$ proceed very fast. In contrast, the other metals exhibit very low precipitation rates in this range of $\mathrm{pH}$ value. When $\mathrm{pH} 4.5$ is attained, nearly all $\mathrm{Fe}$ has been precipitated, while $40 \%$ of the $\mathrm{Al}$ and $83 \%$ of the $\mathrm{Cu}$ are still in the 


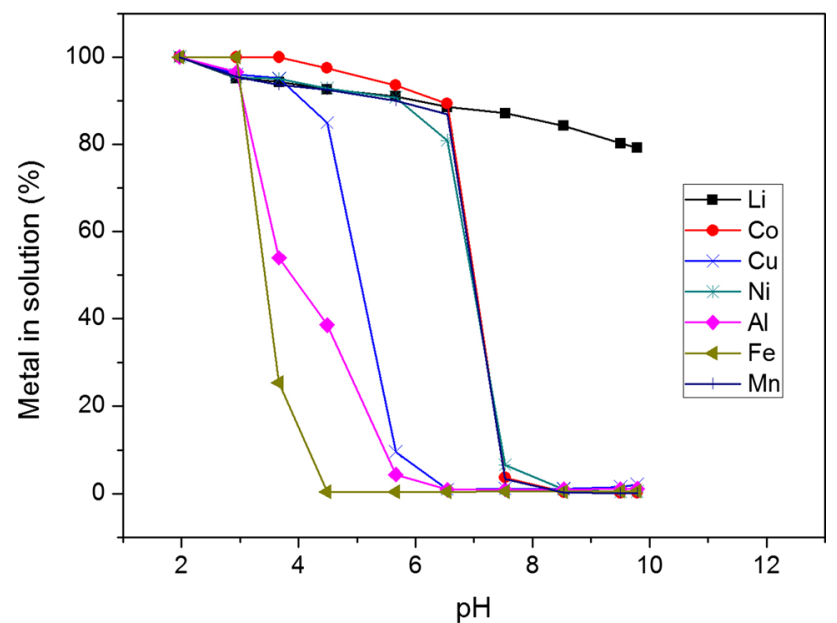

Fig. 13 Metal precipitation using $\mathrm{Na}_{2} \mathrm{CO}_{3}$ solution

solution. Until $\mathrm{pH} 5.7,99.6 \%$ of $\mathrm{Fe}, 96.7 \%$ of $\mathrm{Al}$ and $90.5 \%$ of $\mathrm{Cu}$ are removed from the solution. However, the percentages of $\mathrm{Ni}, \mathrm{Co}$ and $\mathrm{Mn}$ in the solution are still 80, 89 and $87 \%$, respectively. It can be seen that $\mathrm{Ni}, \mathrm{Mn}$ and $\mathrm{Co}$ drastically precipitate since $\mathrm{pH} 6.5$ and more than $99 \%$ at $\mathrm{pH}$ 8.5. At last, $\mathrm{Ni}, \mathrm{Mn}$ and Co contents in solution are lower than $0.7 \%$ when $\mathrm{pH} 9.8$ is reached. Different from the cathode metals, $\mathrm{Li}$ in the solution decreases slowly as the $\mathrm{pH}$ value increases. At the end of the experiment, the Li content in the solution has decreased by $21 \%$.

\section{Metal Sulphide Precipitation}

Metal precipitation using sodium sulphide $\left(\mathrm{Na}_{2} \mathrm{~S} \cdot 9 \mathrm{H}_{2} \mathrm{O}\right)$ is assessed as an effective method to precipitate $\mathrm{Cu}$ and cathode metals. Figure 14 shows the metal contents in solution by changing the concentration of $\mathrm{S}^{2-}$ ions with the titration of $\mathrm{Na}_{2} \mathrm{~S}$. Due to the very low solubility of $\mathrm{CuS}, \mathrm{Cu}$ concentration in solution decreases extremely fast and $82.4 \%$ of $\mathrm{Cu}$ has been precipitated when $\left[\mathrm{S}^{2-}\right]$ is only $1.28 \mathrm{~g} / \mathrm{L}$. When changing $\left[\mathrm{S}^{2-}\right]$ from 2.04 to $4.5 \mathrm{~g} / \mathrm{L}$, the Co in solution decreases from 88 to $56 \%$ and Ni decreases from $87 \%$ to $35 \%$. Furthermore, only $24 \%$ of Co and $3 \%$ of $\mathrm{Ni}$ remain in solution at $7.40 \mathrm{~g} / \mathrm{L}$ of $\left[\mathrm{S}^{2-}\right]$. However, Mn precipitates slowly and there is still $56 \%$ of $\mathrm{Mn}$ in solution. When $\left[\mathrm{S}^{2-}\right]$ has reached $10.33 \mathrm{~g} / \mathrm{L}$, nearly all $\mathrm{Co}$ and $\mathrm{Ni}$ have been precipitated and $38 \%$ of $\mathrm{Mn}$ is still in solution. To further precipitate $\mathrm{Mn}$, more $\mathrm{S}^{2-}$ ions are required.

\section{$\mathrm{Li}_{2} \mathrm{CO}_{3}$ Crystallisation}

Lithium carbonate exhibits the lowest solubility among the possible formed salts as shown in Table 3 . The solubility of $\mathrm{Li}_{2} \mathrm{CO}_{3}$ is $13.3 \mathrm{~g} / \mathrm{L}$ at $25^{\circ} \mathrm{C}$ and decreases to $7.2 \mathrm{~g} / \mathrm{L}$ at

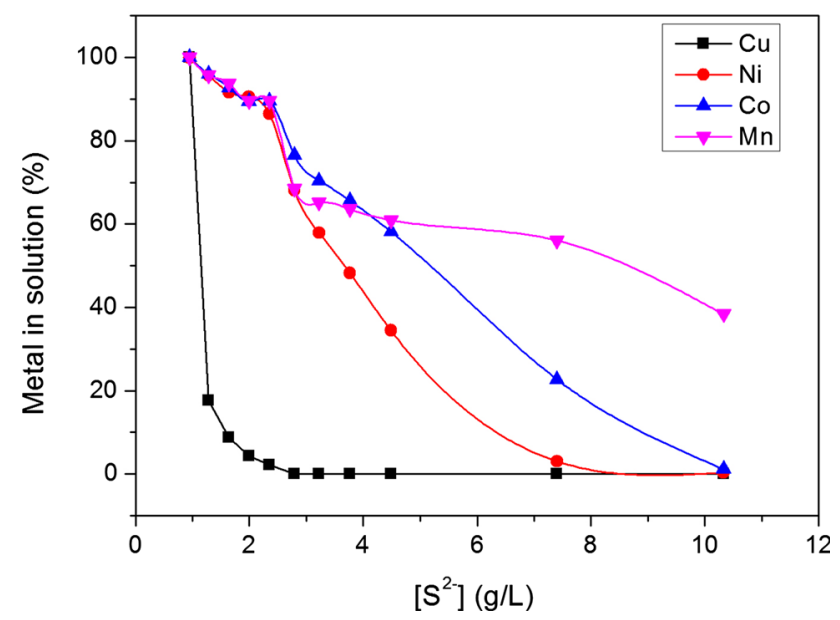

Fig. 14 Metal precipitation using $\mathrm{Na}_{2} \mathrm{~S}^{*} 9 \mathrm{H}_{2} \mathrm{O}$ solution

Table 3 Solubility of all possible crystallisation products at 25, 90 and $100{ }^{\circ} \mathrm{C}$

\begin{tabular}{lllll}
\hline Solubility $(\mathrm{g} / \mathrm{L})$ & $\mathrm{Li}_{2} \mathrm{CO}_{3}(\mathrm{Li})$ & $\mathrm{Na}_{2} \mathrm{CO}_{3}$ & $\mathrm{Li}_{2} \mathrm{SO}_{4}$ & $\mathrm{Na}_{2} \mathrm{SO}_{4}$ \\
\hline $20{ }^{\circ} \mathrm{C}$ & $13.3(2.5)$ & 215 & 348 & 195 \\
$90{ }^{\circ} \mathrm{C}$ & - & 439 & 309 & 427 \\
$100{ }^{\circ} \mathrm{C}$ & $7.2(1.4)$ & - & - & 425 \\
\hline
\end{tabular}

$100{ }^{\circ} \mathrm{C}$ [23]. The lithium carbonate crystallisation is described in Eq. 11:

$\mathrm{Na}_{2} \mathrm{CO}_{3}+2 \mathrm{Li}^{+} \rightarrow \mathrm{Li}_{2} \mathrm{CO}_{3(\mathrm{~s})}+2 \mathrm{Na}^{+}$

Evidently, the XRD pattern (s. Fig. 15) has indicated the existence of $\mathrm{Li}$ salt in the residue as $\mathrm{Li}_{2} \mathrm{CO}_{3}$. The purity of crystallised $\mathrm{Li}_{2} \mathrm{CO}_{3}$ has reached $90.9 \%$, which could be computed from the weight percentage of $\mathrm{Li}(17.2 \%)$ in the product. The compositions of other metals are quite low. Regarding to the efficiency, $59.7 \%$ of Li is crystallised, while the rest remains in the raffinate.

\section{Evaluation of Recycling Products, Efficiency and Feasibility}

In the developed hydrometallurgical process, several products are obtained, such as graphite, cemented copper powder, $\mathrm{Al}$ and $\mathrm{Fe}$ hydroxide, cathode metal $(\mathrm{Co}, \mathrm{Ni}$ and $\mathrm{Mn}$ ) salts and $\mathrm{Li}_{2} \mathrm{CO}_{3}$. In order to evaluate the process, the comprehensive recycling rates of products, purity, marketable value and application of products are summarised in Table 4. Additionally, some representable compositions of the products are shown in Table 5.

The high purity and fine graphite is obtained with high recycling efficiency above $98 \%$. It can be seen that it has a high possibility to be reused in the anode of Li-ion batteries since the purity of recycled graphite is higher than 


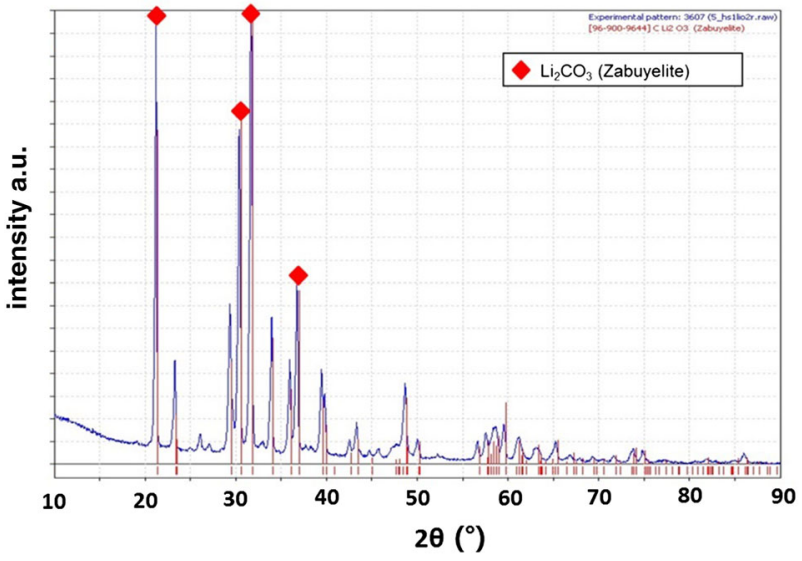

Fig. 15 XRD pattern of the obtained salt from the $\mathrm{Li}$ carbonate crystallisation step

$99.5 \%$. Therefore, the marketable value is apparently higher than the impure graphite. The cemented copper is another valuable product of the recycling process, which has an efficiency of 94-99\% under optimum operating conditions. Hence, it is a very good raw material for the $\mathrm{Cu}$ smelting furnace.

It is found that the $\mathrm{Al}$ and $\mathrm{Fe}$ hydroxide has a moderate purity. The composition of Co is above $4 \%$ showing that the risk to lose the valuable Co and Ni metals in this step is high. Considering the high price of $\mathrm{Co}$ and $\mathrm{Ni}$, the $\mathrm{Fe}$ and Al hydroxide should be further treated.

The cathode metal salt is a very valuable product obtained from the precipitation process. The recycling rates of $\mathrm{Co}, \mathrm{Ni}$ and $\mathrm{Mn}$ can reach $95 \%$ in the developed recycling process. Regarding to the application, the cathode metal salt could serve as the raw material (precursor) to synthesise the new cathode material. At last, the crystallised $\mathrm{Li}_{2} \mathrm{CO}_{3}$ is a very important raw material for $\mathrm{Li}$ industry. $\mathrm{Li}$ composition in crystallised $\mathrm{Li}_{2} \mathrm{CO}_{3}$ ranges from 16.8 to $19.2 \%$ under different operating conditions. Meanwhile, the recovery efficiency ranges from 48 to $64 \%$ in lab scale.

\section{Conclusions}

A highly efficient hydrometallurgical recycling process including pre-treatment for the spent automotive $\mathrm{Li}$-ion batteries has been developed, showing the possibility of using a unique process to recover the high-grade graphite, cathode metal salts and lithium carbonate.

In the leaching step, the temperature of $80{ }^{\circ} \mathrm{C}, \mathrm{H}_{2} \mathrm{O}_{2}$ concentration of $50 \mathrm{~g} / \mathrm{L}, 2 \mathrm{~mol} / \mathrm{L}$ of sulphuric acid or $4 \mathrm{~mol} / \mathrm{L}$ of hydrochloric acid and $2 \mathrm{~h}$ of retention time are recommended for the industrial operation. The recycling rates of valuable metals $(\mathrm{Co}, \mathrm{Ni}, \mathrm{Li}$ and $\mathrm{Cu})$ are above $98.6 \%$ in the verification test. In addition, the recycled graphite has a quite high purity $(>99.5 \%)$ and very fine grain size.

In solution-refining step, the optimum temperature for $\mathrm{Cu}$ cementation is $60{ }^{\circ} \mathrm{C}$. Even though a better kinetic of cementation can be obtained at $80{ }^{\circ} \mathrm{C}$, the dissolution of $\mathrm{Fe}$ powder is at high level and increases the burden of

Table 4 Evaluation of final products in aspect of efficiency, purity, value and application

\begin{tabular}{lllll}
\hline Recycled products & Comprehensive recycling rate in $\%$ & Purity & Value & Application \\
\hline Graphite & $98-100$ & High & High & Li-ion battery anode \\
Copper powder & $94-99$ & Moderate & High & Raw material for Cu metallurgy \\
Al, Fe hydroxide & $60-95$ for Al & Moderate & Middle & Further recovery of Co and Ni \\
Cathode metal salt & $92-99$ for Fe & & & High \\
Li carbonate & $95-98$ for Co, Ni and Mn & High & High & Battery or Li raw material \\
\hline
\end{tabular}

Table 5 Representable compositions of products from hydrometallurgical recycling process (based on different electrode powders)

\begin{tabular}{lllllllll}
\hline Wt\% & $\mathrm{Li}$ & $\mathrm{Co}$ & $\mathrm{Ni}$ & $\mathrm{Mn}$ & $\mathrm{Al}$ & $\mathrm{Fe}$ & $\mathrm{Cu}$ & $\mathrm{C}$ \\
\hline Graphite & 0.05 & $<0.001$ & $<0.001$ & $<0.001$ & 0.04 & 0.05 & $<0.001$ & 99.85 \\
Copper powder & 0.17 & 0.05 & 0.03 & 0.1 & 0.017 & 0.013 & 90 & - \\
Al/Fe hydroxide & 1.44 & 4.32 & 0.07 & 1.32 & 2.34 & 20 & $<0.01$ & - \\
Co, Ni and Mn hydroxide & 1.1 & 35.5 & 1.72 & 0.65 & 2.16 & $<0.002$ & $<0.002$ & - \\
Co, Ni and Mn carbonate & 0.26 & 32.8 & 1.1 & 0.41 & 1.64 & 0.42 & $<0.002$ & - \\
Co, Ni and Mn sulphide & 0.16 & 4.9 & 21.1 & 16.1 & 0.38 & 0.05 & 0.05 & - \\
Li carbonate & 17.2 & $<0.1$ & $<0.1$ & $<0.1$ & $<0.1$ & $<0.1$ & $<0.1$ & $0.8(\mathrm{Na})$
\end{tabular}


following Fe removal. In addition, the calculated activation energy of copper cementation is $12.92 \mathrm{~kJ} / \mathrm{mol}$. Regarding the $\mathrm{Fe}$ and $\mathrm{Al}$ precipitation, more than $60 \%$ of $\mathrm{Al}$ and $92 \%$ of $\mathrm{Fe}$ are recovered. The losses of cathode metals (Co, Ni and $\mathrm{Mn}$ ) are 3-5\% in average. The range of $\mathrm{pH} 3.5-4$ is recommended to make sure the sufficient removal of $\mathrm{Fe}$ and $\mathrm{Al}$ and minimum loss of $\mathrm{Co}, \mathrm{Ni}$ and $\mathrm{Mn}$.

In the cathode metal precipitation step, the hydroxide, carbonate and sulphide precipitation methods are demonstrated to be successful. Nearly, all cathode metals can be precipitated by hydroxide precipitation and carbonate precipitate through increasing $\mathrm{pH}$ value to 10 . In the trail of $\mathrm{Li}_{2} \mathrm{CO}_{3}$ crystallisation, a product with high $\mathrm{Li}_{2} \mathrm{CO}_{3}$ content above $90 \%$ was obtained.

All in all, the utilisation of many extraction and recovery methods in hydrometallurgy overcomes the complexity of spent automotive Li-ion batteries and produces valuable products. Those products, such as battery-level graphite, cathode metal (Co, $\mathrm{Ni}$ and $\mathrm{Mn}$ ) salts and lithium carbonate, could be applied in production of new automotive $\mathrm{Li}$-ion batteries. The close loop of many elements could support the automotive industry in a long run.

Acknowledgments The authors are very grateful for the German Federal Ministry of Education and Research BMBF (Bundesministerium für Bildung und Forschung) for the financial support for the Project No. 03X4601E "Lithiumbatterie Verbundstrukturen", as well as the European Union for the Project "HELIOS-High Energy Lithium-Ion Storage Solutions".

\section{References}

1. Nishi Y (2001) Lithium ion secondary batteries; past 10 years and the future. J Power Sour 100:101-106

2. Wakihara M (2001) Recent developments in lithium ion batteries. Mater Sci Eng 33:109-134

3. Official Journal of the European Union (2006) Directive 2006/66/ EC. http://eur-lex.europa.eu/LexUriServ/LexUriServ.do?uri=OJ: L:2006:266:0001:0014:en:PDF. Accessed on 17.03.15

4. Espinosa D, Bernardes A, Tenório J (2004) An overview on the current processes for the recycling of batteries. J Power Sour 135:311-319

5. Müller T, Friedrich B (2006) Development of a recycling process for nickel-metal hydride batteries. J Power Sour 158:1498-1509
6. Georgi-Maschler T, Friedrich B, Weyhe R, Heegn H, Rutz M (2012) Development of a recycling process for $\mathrm{Li}$-ion batteries. J Power Sour 207:173-182

7. Chéret D (2004) Recycling of rechargeable batteries Li-ion NiMH. In: Proceeding of International Congress for Battery Recycling, Como, Italy

8. Henrion P (2008) Recycling Li-ion batteries at Xstrata nickel. In: Proceeding of International Congress for Battery Recycling, Düsseldorf

9. Tedjar F (2007) Methode for the mixed recycling of lithiumbased anode batteries and cells. US Patent No. 20070196725

10. Lain M (2001) Recycling of lithium ion cells and batteries. J Power Sour 97:736-738

11. Report of LithoRec Project (2012) Braunschweig, Germany

12. A. Krebs (2005) ICBR-International Congress for Battery Recycling

13. Wang Y, Apelian D, Zou H (2013) Method and apparatus for recycling lithium-ion batteries. US Patent No. 20130302226

14. Ferreira D, Prados L, Majuste D, Mansur M (2009) Hydrometallurgical separation of $\mathrm{Al} \mathrm{Co}, \mathrm{Cu}$ and $\mathrm{Li}$ from spent $\mathrm{Li}$-ion batteries. J Power Sour 187:238-246

15. Chen L, Tang X, Zhang Y, Li L, Zeng Z, Yi Zhang (2011) Process for the recovery of Co oxalate from spent Li-ion batteries. Hydrometallurgy 108:80-86

16. Contestabile M, Panero S, Scrosati B (2001) A laboratory-scale Li-ion battery recycling process. J Power Sour 92:65-69

17. Dorella G, Mansur M (2007) A study of the separation of Co from spent Li-ion battery residues. J Power Sour 170:210-215

18. Lee C, Rhee K (2003) Reductive leaching of cathodic active materials from Li ion battery wastes. Hydrometallurgy 68:5-10

19. Mantuano D, Dorella G, Elias R, Mansur M (2006) Analysis of a hydrometallurgical route to recover base metals from spent rechargeable batteries by liquid-liquid extraction with Cyanex 272. J Power Sour 159:1510-1518

20. Shin S, Kim N, Sohn J, Yang D, Kim Y (2005) Development of a metal recovery process from Li-ion battery wastes. Hydrometallurgy 79:172-181

21. Swain B, Jeong J, Lee J, Lee G, Sohn J (2007) Hydrometallurgical process for recovery of Co from waste cathodic active material generated during manufacturing of $\mathrm{Li}$ ion batteries. J Power Sour 167:536-544

22. Freitas M, Garcia E (2007) Electrochemical recycling of cobalt from cathodes of spent lithium-ion batteries. J Power Sour 171:953-959

23. Gupta C, Mukherjee T (1990) Hydrometallurgy in extraction processes. CRC Press, USA

24. Miller J, Beckstead L (1973) Surface deposit effects in the kinetics of copper cementation by iron. Metall Trans 4:1969-1973

25. El-Batouti M (2005) Removal of copper metal by cementation using a rotating iron cylinder. J Colloid Interface Sci 283:123-129

26. Ismael M (2003) Iron recovery from sulphate leach liquors in zinc hydrometallurgy. Miner Eng 16:31-39 